\title{
Starch Levels in Refrigerated and Frozen Chicken Based Meat Products
}

\author{
Renata A. Labanca; Cristiane M. G. Silva; M. Beatriz A. Glória* \\ Departamento de Alimentos, Faculdade de Farmácia, Universidade Federal de Minas Gerais. Av. Olegário \\ Maciel 2360, Belo Horizonte, MG 30180-112 Brazil Fax: 0313379076
}

\begin{abstract}
The levels of starch were determined in chicken based meat products commercialized in Belo Horizonte, MG, Brazil, from December 1996 to March 1997. Samples were analyzed for moisture and starch contents. Starch was acid hydrolyzed and the resulting glucose was determined at $620 \mathrm{~nm}$ after reaction with anthrone. The method was observed to be accurate (92.7\% recovery), precise $(C V=3.0 \%)$, sensitive (quantification limit $=1.25 \mathrm{~g} / 100 \mathrm{~g})$ and simple in the determination of starch in meat products. Among products analyzed, starch was detected in $100 \%$ of meat balls and nuggets samples, in $60 \%$ of the sausage, 50\% of the bologna and $30 \%$ of the frankfurter. Starch was not detected in hamburger samples analyzed. Higher mean starch levels were found in nuggets $(14.85 \mathrm{~g} / 100 \mathrm{~g})$ followed by meat balls $(4.45 \mathrm{~g} / 100 \mathrm{~g})$, sausage $(1.73 \mathrm{~g} / 100 \mathrm{~g})$, bologna $(1.14 \mathrm{~g} / 100 \mathrm{~g})$ and frankfurter $(0.57 \mathrm{~g} / 100$ g). Mean moisture content varied from 35.68 in sausage to $46.24 \mathrm{~g} / 100 \mathrm{~g}$ in nuggets. No significant correlation was observed between moisture and starch contents. Every sample of bologna and $90 \%$ of the frankfurter contained starch levels according to the Brazilian legislation. Starch levels varied considerably within brands as well as within lots of the same brand.
\end{abstract}

Key words: starch, chicken based meat products, anthrone method.

\section{INTRODUCTION}

The production of poultry meat has increased dramatically over the past 20 years, probably due to low production costs, short grow-out period, advanced production technology, improved feeds and to the high food conversion rate. This increased production associated with small price fluctuation, allowed poultry meat to be a viable alternative as raw material for the manufacture of different poultry based products, among them, refrigerated, cured and frozen products. These processed products are gaining popularity because they have longer shelf-life than fresh meat and are easy to prepare (GODOY FILHO, 1997; SILVA, 1995).

The addition of non-meat ingredients (e.g. dairy products, vegetable proteins or starch) is allowed during manufacture of some meat products. Starch can be added in order to improve product quality by affecting water holding capacity, binding properties, gelling ability and cryoprotection (GARCIA et al, 1985; GOMIDE et al, 1985; JIMENEZ-COLMENERO et al, 1996; LAUCK, 1975; MAURO, 1996; TAKAHASHI, 1993). According to Brazilian legislation (BRASIL, 1962), starch can be added to frankfurter and to bologna at levels up to 2 and 5\%, respectively. However, starch is sometimes added at levels higher than the established to reduce production costs and increase yield and profit (AUED et al, 1990; SOUZA et al, 1990; TAKINO et al, 1985), which is considered adulteration or fraud. The levels of starch in beef and pork based meat products have been investigated. According to Table 1, values above the limits established by the Brazilian legislation have been detected (TAKINO et al, 1985). Data is not available related to starch level in poultry based meat products.

\footnotetext{
* Author for correspondence
} 
Table 1 - Starch levels in beef and pork based meat products and compliance with Brazilian legislation

\begin{tabular}{|c|c|c|c|c|c|}
\hline \multicolumn{2}{|c|}{ Samples } & \multicolumn{2}{|c|}{$\operatorname{Starch}(g / 100 g)$} & \multirow{2}{*}{$\begin{array}{l}\text { Attendance to } \\
\text { legislation }^{3}(\%)\end{array}$} & \multirow[t]{2}{*}{ References } \\
\hline Type & $\mathbf{N}^{1}$ & Range & Mean & & \\
\hline \multicolumn{6}{|c|}{ Frankfurter } \\
\hline & 5 & $2.55-9.71$ & $5.24 \pm 2.86$ & 0 & AUED et al (1990) \\
\hline & 6 & $3.77-12.88$ & $8.14 \pm 3.86$ & 0 & BARBOSA et al (1995) \\
\hline & 5 & $1.38-13.55$ & $6.24 \pm 6.09$ & 40 & GARCIA et al (1985) \\
\hline & 9 & nd - 5.70 & $2.40 \pm 2.02$ & 56 & GOMIDE et al (1985) \\
\hline & 20 & $1.57-9.68$ & $3.95 \pm 3.85$ & 50 & HSU et al (1977) \\
\hline & 20 & $1.08-5.84$ & $2.64 \pm 1.53$ & 50 & SOUZA et al (1990) \\
\hline & 37 & $1.61-18.41$ & -2 & 3 & TAKINO et al (1985) \\
\hline \multicolumn{6}{|l|}{ Bologna } \\
\hline & 3 & $3.69-3.84$ & -2 & 100 & BRUM \& TERRA (1989) \\
\hline & 19 & $1.68-6.17$ & $3.28 \pm 1.32$ & 11 & SOUZA et al (1990) \\
\hline & 52 & $5.49-18.2$ & -2 & 0 & TAKINO et al (1985) \\
\hline
\end{tabular}

${ }^{1}$ Number of samples analyzed. ${ }^{2}$ Information not available. ${ }^{3}$ According to Brazilian legislation levels of starch incorporated into frankfurters and bologna are limited to 2 and 5\%, respectively.

Several methods have been used for the determination of starch in meat based products. Due to the complex nature of the sample, analysis is preceded by sample purification to remove interferences such as fat, protein and simple sugars (AUED et al, 1990). Starch is then hydrolyzed (acid or enzymatic hydrolysis) and the resulting sugar can be quantified by volumetric (titration) or spectrophotometric methods. Fehling, a volumetric method, presents technical difficulties related to the visualization of the endpoint due to formation of abnormal colorations and/or foam from soy bean saponins; overestimation of results due to the formation of reducing compounds during operation; and applicability only to samples containing starch levels higher than 3\% (AUED et al, 1990; GARCIA et al, 1985; SOUZA et al, 1990; TAKINO et al, 1985). Spectrophotometric procedures such as the Somogyi-Nelson (AUED et al, 1990; BARBOSA et al, 1995), the 3,5dinitrosalicylic acid (BARBOSA et al, 1995) and the anthrone method (MORAES \& CHAVES, 1988; STEVENS \& CHAPMAN, 1955) have been used, and are considered the most suitable for the determination of starch in meat products. According to MORAES \& CHAVES (1988), the anthrone method was observed to be accurate, precise and simple in the determination of starch in samples containing levels of 8 to $13 \mathrm{~g} / 100 \mathrm{~g}$. Therefore, it would be interesting to investigate the application of this method for routine quality control of meat based products.

The objective of this work was to determine the levels of starch in chicken based meat products, using a method based in the acid hydrolysis and spectrophotometric detection after reaction with anthrone.

\section{MATERIAL AND METHODS}

Chicken based meat products, with origin certified by the Serviço de Inspeção Federal (Federal Inspection Service), including frankfurter (hot dog), bologna, sausage, hamburger, meat balls and nuggets (10 samples of each), were purchased at the retail market of Belo Horizonte, MG, Brazil, from December 1996 to March 1997. Samples were kept under refrigerated or frozen storage until analysis, which was performed before products expiration date.

In order to standardize the methodology, known quantities of starch were added to $100 \mathrm{~g}$ of bologna and nuggets, in duplicate. Samples were analyzed before and after starch addition and percent recovery was determined. 
Samples were ground, homogenized and analyzed for moisture (IAL, 1985) and starch contents in triplicate. For starch determination, extraction and acid hydrolysis were performed according to the methodology described by AUED et al (1990), with modifications. Its quantification was carried out according to the procedure described by MORAES \& CHAVES (1988) and STEVENS \& CHAPMAN (1955) as follows: fat was removed from samples $(0.5 \mathrm{~g})$ using five $5 \mathrm{~mL}$ portions of diethyl ether, mixing thoroughly, and centrifuging at 1500 rpm for 5 minutes. Simple sugars were eliminated through eight $5 \mathrm{~mL}$ successive extractions with $80 \%$ ethanol $\left(80^{\circ} \mathrm{C}\right)$, mixing thoroughly, and centrifuging at $1500 \mathrm{rpm}$ for 5 minutes. Supernatants were discarded. After drying the residue at $70^{\circ} \mathrm{C}$ for 20 minutes, acid hydrolysis of starch was accomplished at $100^{\circ} \mathrm{C}$ with $10 \mathrm{~mL}$ of $0.5 \mathrm{~N}$ sulfuric acid (Merck, Darmstadt, Germany). The duration of the hydrolysis was 1 hour for frankfurter, bologna, sausage, hamburger and meat balls and 2 hours for nuggets, shaking occasionally. Contents were transferred to a volumetric flask of $500 \mathrm{~mL}$ and the volume was brought up with distilled water. A $2 \mathrm{~mL}$ volume of this hydrolizate was added to $10 \mathrm{~mL}$ of 9,10-dihydro-9oxoanthracene (anthrone) under acidic conditions $(0.1 \mathrm{~g} / 100 \mathrm{~mL}$ of $76 \%$ sulfuric acid), kept in a boiling water bath for 10 minutes and then cooled in the dark for color formation (20 min). A blank was prepared with distilled water instead of sample extract. The absorbance was determined at $620 \mathrm{~nm}$ in a Shimadzu UV-Vis 160 spectrophotometer (Kyoto, Japan).

The concentration of glucose was calculated by the standard curve $\mathrm{Y}=0.0026 \mathrm{x}+0.0123$, where $\mathrm{Y}=$ absorbance (sample - blank) and $\mathrm{x}=$ glucose concentration $\left(r^{2}=0.9981\right)$. The concentration of starch was calculated by multiplying the value obtained for glucose by the conversion factor 0.9 .

\section{RESULTS AND DISCUSSION}

Initial studies indicated low recoveries (60 $70 \%$ ) for products containing high starch levels suggesting that one hour was not enough for complete hydrolysis of the starch. Studies undertaken to investigate the ideal time for hydrolysis of samples, indicated that two hours were necessary for products containing starch levels higher than $10 \mathrm{~g} / 100 \mathrm{~g}$. Taking this criteria into consideration, mean recovery of 92.7\% ( $\mathrm{CV}=3.0 \%)$ was obtained for bologna and nuggets spiked with different amounts of starch as shown in Table 2. The quantification limit, determined according to POMERANZ \& MELOAN (1994) and WERNIMONT (1985), was $1.25 \mathrm{~g} / 100 \mathrm{~g}$.

The obtained results confirm that this method is accurate, precise and sensitive. Furthermore, it is simple, requires little manipulation and uses small amounts of reagents and samples. Therefore, it is efficient for the routine quality control of chicken based meat products.

Among products analyzed, starch was present in $100 \%$ of meat balls and nuggets samples, in $60 \%$ of sausage, $50 \%$ of bologna and $30 \%$ of frankfurter. Starch was not detected in hamburger samples.

Higher mean starch levels (Table 3) were detected in nuggets $(14.85 \mathrm{~g} / 100 \mathrm{~g})$. This is consistent with its formulation and processing (GODOY FILHO, 1997), which consists in covering the meat with coating liquid (cereal flour, modified starch and sugars) and with coating flour (wheat flour; breading; modified starch; rice, corn, cassava and potato flakes; crackers; etc.). The meat balls contained mean starch levels of $4.45 \mathrm{~g} / 100 \mathrm{~g}$, sausage contained $1.73 \mathrm{~g} / 100 \mathrm{~g}$, bologna contained $1.14 \mathrm{~g} / 100 \mathrm{~g}$ and frankfurter $0.57 \mathrm{~g} / 100 \mathrm{~g}$. 
Table 2 - Recovery of starch from bologna and nuggets spiked with different starch levels

\begin{tabular}{|c|c|c|c|}
\hline \multicolumn{2}{|c|}{ Starch level $^{1}(\mathrm{~g} / 100 \mathrm{~g})$} & \multirow{2}{*}{$\begin{array}{c}\text { Recovery } \\
(\%)\end{array}$} & \multirow{2}{*}{$\begin{array}{c}\text { Mean recovery } \\
\pm \text { sd }\end{array}$} \\
\hline Added & Found & & \\
\hline \multicolumn{4}{|l|}{ Bologna } \\
\hline \multirow[t]{2}{*}{3.0} & 8.02 & 96.9 & $95.5 \pm 2.0$ \\
\hline & 7.96 & 94.4 & \\
\hline \multirow[t]{2}{*}{4.0} & 9.49 & 97.2 & $94.0 \pm 4.4$ \\
\hline & 9.24 & 90.9 & \\
\hline \multirow[t]{2}{*}{5.0} & 10.06 & 89.2 & $90.0 \pm 1.1$ \\
\hline & 10.14 & 90.8 & \\
\hline \multirow[t]{2}{*}{6.0} & 11.09 & 91.5 & $92.6 \pm 1.5$ \\
\hline & 11.05 & 90.9 & \\
\hline \multicolumn{4}{|l|}{ Nuggets } \\
\hline \multirow[t]{2}{*}{2.5} & 10.75 & 90.0 & $93.0 \pm 4.2$ \\
\hline & 10.90 & 96.0 & \\
\hline \multirow[t]{2}{*}{5.0} & 13.20 & 93.9 & $92.6 \pm 1.7$ \\
\hline & 13.07 & 91.4 & \\
\hline \multirow[t]{2}{*}{10.0} & 17.51 & 90.1 & $92.5 \pm 3.4$ \\
\hline & 17.99 & 94.9 & \\
\hline
\end{tabular}

${ }^{1}$ The levels of starch in bologna and nuggets prior to starch addition were 5.6 and $8.5 \mathrm{~g} / 100 \mathrm{~g}$, respectively.

The levels of starch detected in samples of frankfurter and bologna analyzed were lower than those detected in beef and pork based products (Table 1). Moreover, compliance with Brazilian legislation was higher for chicken (100\% of bologna and $90 \%$ of frankfurter samples) compared to beef and pork based products.

There was large variability on moisture contents expressed in $\mathrm{g} / 100 \mathrm{~g}$ of the products: 35.75 to 40.47 (mean $38.05 \pm 1.42$ ) for frankfurter, 37.27 to 44.60 (mean $41.16 \pm 2.69$ ) for bologna, 22.32 to 42.84 (mean $35.68 \pm 7.04$ ) for sausage, 30.10 to 44.28 (mean $37.51 \pm 4.74$ ) for hamburger, 30.59 to 48.41 (mean $38.87 \pm 4.83$ ) for meat balls and 41.77 to 49.49 (mean $46.24 \pm 2.75$ ) for nuggets. No significant correlation was observed between moisture content and starch level.
The levels of starch detected in different brands of a product varied significantly ( $\mathrm{p} \leq 0.05$, Duncan test), especially in meat balls and nuggets. Such differences could be related to distinct formulations used by different industries and to the lack of standards of identity and quality for these new products. The significantly lower value found in nuggets from brand $\mathrm{D}$, is probably related to the fact that it was a 'light product' and had a thinner coating layer compared to the other samples. Significant variation was also observed on starch levels among products of different lots from a brand. Larger coefficients of variation were observed for frankfurter $(\mathrm{CV}=170 \%)$ and bologna ( $\mathrm{CV} \leq 118 \%)$. These results suggest that, as reported by GOMIDE et al (1985) for Vienna frankfurter, there seems to be a lack of standardization on product formulations from industry to industry as well as within different lots of an industry. 
Table 3 - Starch levels in different types and brands of chicken based meat products

\begin{tabular}{|c|c|c|c|}
\hline \multirow{2}{*}{$\begin{array}{l}\text { Meat products/ } \\
\text { brands }\end{array}$} & \multirow{2}{*}{$\begin{array}{c}\text { Number of } \\
\text { samples } \\
\end{array}$} & \multicolumn{2}{|c|}{ Starch levels (g/100 g) } \\
\hline & & Range & Mean \pm sd \\
\hline \multicolumn{4}{|l|}{ Frankfurter } \\
\hline A & 10 & nd -2.62 & $0.57 \pm 0.96$ \\
\hline total & 10 & nd - 2.62 & $0.57 \pm 0.96$ \\
\hline \multicolumn{4}{|l|}{ Bologna } \\
\hline $\mathbf{A}$ & 4 & nd -3.04 & $1.29 \pm 1.54^{\mathrm{a}}$ \\
\hline B & 6 & nd -2.89 & $1.04 \pm 1.23^{\mathrm{a}}$ \\
\hline total & 10 & nd -3.04 & $1.14 \pm 1.28$ \\
\hline \multicolumn{4}{|l|}{ Sausage } \\
\hline A & 4 & nd -3.19 & $1.38 \pm 1.63^{\mathrm{a}}$ \\
\hline B & 4 & $1.75-4.93$ & $2.95 \pm 1.38^{\mathrm{a}}$ \\
\hline $\mathbf{C}$ & 2 & nd & 0.00 \\
\hline total & 10 & nd -4.93 & $1.73 \pm 1.70$ \\
\hline \multicolumn{4}{|l|}{ Hamburger } \\
\hline A - E & 10 & nd & 0.00 \\
\hline \multicolumn{4}{|l|}{ Meat balls } \\
\hline $\mathbf{A}$ & 2 & $4.72-5.15$ & $4.94 \pm 0.31^{\mathrm{a}}$ \\
\hline B & 2 & $3.14-3.31$ & $3.22 \pm 0.12^{\mathrm{b}}$ \\
\hline $\mathbf{C}$ & 3 & $2.48-3.71$ & $2.90 \pm 0.71^{\mathrm{b}}$ \\
\hline D & 3 & $5.48-8.43$ & $6.51 \pm 1.67^{\mathrm{a}}$ \\
\hline total & 10 & $2.48-8.43$ & $4.45 \pm 1.83$ \\
\hline \multicolumn{4}{|l|}{ Nuggets } \\
\hline A & 3 & $24.36-46.80$ & $35.17 \pm 6.70^{\mathrm{a}}$ \\
\hline B & 2 & $11.93-19.13$ & $16.61 \pm 4.60^{\mathrm{c}}$ \\
\hline C & 3 & $19.80-26.67$ & $22.79 \pm 3.52^{\mathrm{b}}$ \\
\hline D & 2 & $3.90-4.69$ & $4.30 \pm 0.56^{\mathrm{d}}$ \\
\hline total & 10 & 3.90 - 46.80 & $\mathbf{2 4 . 8 5} \pm 9.45$ \\
\hline
\end{tabular}

Mean values ( \pm standard deviation - sd, calculated using zero for levels below quantification limit - nd $\leq 1.25 \mathrm{~g} / 100$ g) with the same superscript for the same type of product do not differ significantly ( $\mathrm{p} \leq 0.05$, Duncan test).

\section{RESUMO}

Os teores de amido foram determinados em produtos a base de frango comercializados em Belo Horizonte, MG, no período de dezembro de 1996 a março de 1997. As amostras foram analisadas quanto aos teores de umidade e amido. O amido foi submetido a hidrolise ácida e a glicose resultante foi determinada a $620 \mathrm{~nm}$ após reação com antrona. O método apresentou exatidão ( $92,7 \%$ de recuperação), precisão ( $\mathrm{CV}$ $=3,0 \%$ ), sensibilidade (limite de quantificação $=1,25 \mathrm{~g} / 100 \mathrm{~g}$ ) e simplicidade na determinação de amido em produtos cárneos. Dentre os produtos analisados, amido foi detectado em $100 \%$ das amostras de almôndega e empanado,
$60 \%$ das de lingüiça, $50 \%$ das de mortadela e $30 \%$ das de salsicha. Amido não foi detectado nas amostras de hambúrguer analisadas. Teores médios mais elevados de amido foram encontrados em empanado $(14,85 \mathrm{~g} / 100 \mathrm{~g})$ seguido de almôndegas $(4,45 \mathrm{~g} / 100 \mathrm{~g})$, lingüiça $(1,73 \mathrm{~g} / 100 \mathrm{~g})$, mortadela $(1,14 \mathrm{~g} / 100 \mathrm{~g})$ e salsicha $(0,57 \mathrm{~g} / 100 \mathrm{~g})$. $\mathrm{O}$ teor médio de umidade variou de 35,68 em lingüiça a 46,24 $\mathrm{g} / 100 \mathrm{~g}$ em empanado. Todas as amostras de mortadela e $90 \%$ das de salsicha atenderam a legislação vigente quanto aos teores de amido. Foi observada variação nos teores de amido entre produtos de diferentes marcas e de uma mesma marca. 


\section{REFERENCES}

Aued, S.; Carvalho, J.B.; Tavares, M.; Zanelatto, A.M.; Bacetti, L.B. Determinação de amido em salsichas: comparação entre os métodos de Fehling e de Somogyi-Nelson e avaliação de metodologia para extração do amido. Rev. Inst. Adolfo Lutz, v.50, n.1/2, p.251-256, 1990.

Barbosa, N.R.; Mendes, B.A.; Chicourel, E.L. Determinação de amido em salsichas: comparação entre os métodos espectrofotométricos de Somogyi-Nelson com o do ácido 3,5dinitrossalicílico. Rev. Bras. Anal. Alim., v.1, p.31-40, 1995.

BRASIL. MINISTÉRIO DA AGRICULTURA DIPOA. Regulamento e Inspeção Industrial e Sanitária de Produtos de Origem Animal; Decreto no. 1.255 de 25 de junho de 1962 .

Brum, M.A.; Terra, N.M. Aspectos químicos e microbiológicos de mortadela. Rev. Nac. Carne, v.151, p.49-50, 1989.

Garcia, E.; Cordenunsi, B.R.; Lajolo, F.M. Determinação de amido em embutidos: comparação entre o método de Fehling e método enzimático. Ciênc. Tecnol. Aliment., v.5, p.3946, 1985.

Godoy Filho, J.H. Aspectos tecnológicos de produtos empanados de frango. Rev. Nac. Carne, v.246, p.40-44, 1997.

Gomide, L.A.M.; Pereira, A.S.; Gomes, J.C. Avaliação físico-química de salsichas Viena enlatadas. Aliment., v.76, p.26-29, 1985.

Hsu, L.A.; Ciampi, C.M.S.; Delazari, I.; Lazarine, V.B.; Galvão, L.C.A.; Figueiredo, I.O. Avaliação da qualidade de salsichas. Bol. Inst. Tecnol. Aliment., n.53, p.93-107, 1977.

IAL (Instituto Adolfo Lutz). Normas analíticas do Instituto Adolfo Lutz: métodos químicos e físicos para análise de alimentos. São Paulo: IAL. 1985. v.1, p.340-344.

Jimenez-Colmenero, F.; Barreto, G.; Fernandez, P.; Carballo, J. Frozen storage of bologna sausages as a function of fat content and levels of added starch and egg white. Meat Sci., v.42, n.3, p.325332, 1996.
Lauck, R.M. The functionality of binders in meat emulsion. J. Food Sci., v.40, p.736-740, 1975.

Mauro, D.J. An update on starch. Cereal Food World, v.41, n.10, p. 776-778,780, 1996.

Moraes, O.M.G.; Chaves, M.B. Método espectrofotométrico para a determinação de amido em produtos cárneos. In: Encontro Nacional de Analistas de Alimentos, $4^{\circ}$, Belo Horizonte, 1988, p. 281.

Pomeranz, Y.; Meloan, C.E. Food Analysis: Theory and Practice, 3 ed., New York: Chapman \& Hall, 1994.

Souza, P.A.; Souza, H.B.A.; Faleiros, R.R.S. Avaliação química de algumas marcas de salsichas e mortadelas. Ciênc. Tecnol. Alim., v.10, n.1, p.109-119, 1990.

Silva, J.C.T. Por que a avicultura se expande. Rev. Nac. Carne, v.222, p.50-57, 1995.

Stevens, F.J.; Chapman, R.A. The determination of starch in meat products with the anthrone reagent. J. Assoc. Offic. Anal. Chem., v.38, n.2, p.202210, 1955.

Takahashi, G. Ingredientes e suas funções na fabricação de produtos cárneos. Rev. Nac. Carne, v.199, p.14-18, 1993.

Takino, M.; Komatsu, I.; Galli, F. A porcentagem de amido na salsicha e mortadela fabricada em São Paulo. Ciênc. Cult., v.29, p.124-125, 1985.

Wernimont, G.T. Use of statistics to develop and evaluate analytical methods. Arlington: Association of Official Analytical Chemists, 1985, $183 \mathrm{p}$. 